\title{
Pendampingan Implementasi Model Pembelajaran OIDDE untuk Meningkatkan Keterampilan Pembelajaran Berorientasi Etika di MA Muhammadiyah 1 Plus Malang
}

\author{
Atok MIftachul Hudha ${ }^{1 *}$, Husamah ${ }^{2}$ \\ 1,2 Pendidikan Biologi FKIP Universitas Muhammadiyah Malang
}

\section{A R T I C L E I N F O}

\section{Article history:}

Received 20 May 2019

Received in revised form

10 June 2019

Accepted 30 July 2019

Available online 30 August 2019

Kata Kunci:

Model OIDDE

Pembelajaran Berorientasi

Etika, Keterampilan

Pembelajaran

Keywords:

Ethical oriented learning,

learning skills, OIDDE

model,

\begin{abstract}
A B S T R A K
Berperilaku etis tidak serta merta dapat dimunculkan, sehingga diperlukan proses pembentukan sikap berperilaku etis bagi siswa, dan salah satunya melalui pendidikan (yang menuntut peran aktif guru, berupa penerapan pembelajaran berorientasi etika). Artikel ini bertujuan mendeskripsikan implementasi kegiatan pendampingan implementasi model pembelajaran OIDDE di MA Muhammadiyah 1 Plus Malang. Subjek pengabdian ini adalah guru MA Muhammadiyah I Plus Malang sebanyak 21 orang. Kegiatan pengabdian dilaksanakan selama 3 bulan. Metode pelaksanaan, yaitu diskusi, ceramah interaktif, praktik, dan pemodelan. Evaluasi pengabdian dilakukan terhadap aspek proses. Hasil evaluasi proses menunjukkan pengabdian terlaksana sesuai rencana, $100 \%$ guru hadir dengan antusias (serius mengikuti semua sesi pelatihan sampai selesai), $90 \%$ aktif bertanya, dan ada perwakilan yang tunjuk oleh pihak madrasah untuk menjadi guru model.
\end{abstract}

\section{A B S T R A C T}

Ethical behavior does not necessarily arise, so that a process of forming ethical attitudes is needed for students, and one of them is through education (which requires the active role of the teacher, in the form of ethical oriented learning). This article aims to describe the implementation of mentoring activities for the implementation of the OIDDE learning model at MA Muhammadiyah 1 Plus Malang. The subject of this service was 21 teachers of the MA Muhammadiyah I Plus Malang. Service activities are held for 3 months. Implementation methods, namely discussions, interactive lectures, practices, and modeling. Service evaluation is carried out on aspects of the process. The results of the process evaluation showed that service was carried out according to plan, $100 \%$ of teachers were enthusiastic (seriously following all training sessions to completion), $90 \%$ actively asked, and there were representatives appointed by the madrasa to become model teachers.

\footnotetext{
* Corresponding author.

E-mail addresses: atok1964@gmail.com (Atok MIftachul Hudha)
} 


\section{Pendahuluan}

Etika memiliki peran penting dalam kehidupan (Banks, 2016; Elliott, 2009; Gülcan, 2015). Etika mengacu pada kode perilaku yang memandu seseorang dalam berurusan dengan orang lain (Gilman, 2005; Lesna-Wierszolowicz, 2012). Kemajuan ilmu pengetahuan dan teknologi serta cepatnya arus globalisasi berkontribusi pada kompleksitas kehidupan sosial dan menuntut perlunya pengarusutamaan etika (Chowdhury, 2016; Weisman, 2013).

Menurut Maftuh (2016) sumber daya manusia abad ke-21 harus memiliki setidaknya tujuh kompetensi, yaitu 1) berpikir kritis dan pemecahan masalah (critical thinking and problem solving); 2) kreatif dan inovatif (creative and innovative skills); 3) berperilaku etis (ethical behavior); 4) fleksibel dan adaptif (flexibility and adaptability); 5) mampu menguasai teknologi informasi dan literasi media (ICT and media literacy); 6) interpersonal dan ketrampilan berkolaborasi (interpersonal and collaboration skills); 7) mampu bersosialisai dan berinteraksi antar budaya (social and cross cultural interaction skills). Dari ketujuh kompetensi yang diharapkan, maka salah satu penekanan kompetensi sumber daya manusia abad ke-21 adalah berperilaku etis.

Berperilaku etis bagi siswa tidak serta merta dapat dimunculkan, sehingga diperlukan proses pembentukan sikap berperilaku etis, dan salah satunya melalui pendidikan (pembelajaran di kelas). Pendidikan menjadi perwujudan value bond atau sarat nilai, maka menginternalisasikan nilai-nilai etika merupakan salah satu fungsi pendidikan (Latif, 2016). Pendidikan juga mengemban tugas untuk menjaga dan mengembangkan etika dalam hidup agar sejalan dengan perkembangan zaman (Iorga, Ciuhodaru, \& Romedea, 2013). Menurut Gluchmanova (2015) dalam konteks sekolah dan dengan dukungan kebijakan, program, dan praktik sekolah, pendidikan berbasis etika membantu siswa untuk mengembangkan, misalnya pengetahuan dan kesadaran mendalam tentang budaya mereka sendiri dan budaya orang lain.

Pembelajaran berorientasi etika penting untuk menjawab kompetensi sumber daya manusia di abad ke-21. Pembelajaran berorientasi etika bertujuan untuk mengurangi pembelajaran yang hanya berorientasi pada pengetahuan (kognitif). Hal ini penting karena sebagaimana menurut Akbar (2011) selama ini pembelajaran di sekolah cenderung berorientasi kognitif, bahkan overcognitive. Pembelajaran overcognitive memberikan dampak kurang baik terhadap pembentukan sikap dan perilaku siswa. Oleh sebab itu, untuk menjawab persoalan perlu dikembangkan pembelajaran berorientasi etika yang dilakukan secara terus-menerus. Setyaningrum dan Husamah (2011), menegaskan bahwa pembelajaran yang cenderung dominan pada aspek kognitif berdampak pada timbulnya degradasi moral dan etika akibat pelanggaran nilai-nilai moral dan etika.

Berkaitan dengan pembelajaran berorientasi etika, salah satu sekolah atau madrasah yang perlu mendapat perhatian adalah Madrasah Aliyah (MA) Muhammadiyah 1 Plus Malang. MA Muhammadiyah 1 Plus Malang berlokasi di Jalan Baiduri Sepah No. 27 Tlogomas, Lowokwaru Kota Malang, Jawa Timur. Visi yang dikedepankan adalah menjadi sekolah (madrasah) yang unggul dalam sains dengan dasar bahasa Arab, bahasa Inggris, serta berketerampilan. Untuk merealisasikan visi sekolah maka dijabarkan tujuh misi sekolah, yaitu (1) memupuk minat dan bakat siswa, sehingga setiap siswa dapat berkembang sesuai dengan proses yang dimiliki; (2) membentuk siswa berakhlakul karimah; (3) menciptakan lingkungan bersih dan agamis; (4) membentuk pola piker kritis dan ilmiah; (5) menumbuhkan dan menjaga sikap disiplin serta bertanggungjawab dalam bermasyarakat; (6) menciptakan suasana belajar siswa aktif dengan berbasis IT; dan (7) meningkatkan keterampilan dan kemampuan berbahasa Inggris dan bahasa Arab.

Berdasarkan hasil observasi dan wawancara yang dilakukan oleh tim pelaksana pengabdian dengan Wakil Kepala Sekolah bidang Humas MA Muhammadiyah I Plus Malang, Bapak Slamet Hariyadi, diperoleh data bahwa salah satu bentuk kegiatan untuk mencapai misi sekolah adalah kerohanian yang dilaksnakan di waktu pagi hari sebelum kegiatan pelajaran dimulai. Kegiatan kerohanian pagi hari berlangsung hari Senin sampai Jum'at, dimulai pukul 6.55 WIB hingga pukul 7.25 WIB. Bentuk kegiatannya berupa kuliah tujuh menit (kultum) yang disampaikan dalam bahasa Arab dan bahasa Inggris, dan dilanjutkan Sholat Dhuha. Selanjutnya, pada pukul 7.30 WIB santri akan masuk kelas untuk mengikuti pelajaran yang telah dijadualkan di setiap kelas.

Pembelajaran berorientasi etika belum terintegrasi secara nyata dalam pembelajaran di kelas melalui mata pelajaran. Semua mata pelajaran di MA Muhammadiyah I Plus Malang belum menjadikan aspek etika sebagai hal yang khusus. Para guru atau ustadz dan ustadzah mengajar mata pelajaran yang diajarkannya sebagaimana lazimnya pembelajaran yang selama ini diberikan (konvensional). Berdasarkan hal ini, maka pada hari Jum'at, 11 Januari 2019 antara Tim Pengabdian dengan pihak MA Muhammadiyah I Plus Malang melakukan diskusi akan pentingnya pembelajaran berorientasi etika. Padahal menurut Hudha, Amin, Sumitro, dan Akbar (2018) etika terintegrasi dalam mata pelajaran sehingga etika selain dibentuk melalui budaya sekolah, juga dikuatkan melalui mata pelajaran di kelas. 
Berdasarkan hasil diskusi yang dilakukan menghasilkan kesepatan bahwa untuk membentuk sikap atau perilaku etis melalui pembelajaran, perlu dilakukan transfer of knowledge kepada para guru dalam bentuk pendampingan pengenalan dan implementasi model pembelajaran dimaksud, yaitu model pembelajaran OIDDE. Untuk menjawab kondisi demikian, tentu dibutuhkan pendekatan, model, metode, atau strategi pembelajaran yang tepat dan layak. Salah satu bentuk model pembelajaran yang tepat dan layak untuk melaksanakan pembelajaran berorientasi etika adalah model pembelajaran OIDDE (Fariati, Hudha, \& Husamah, 2017; Hudha et al., 2018; Hudha, Amin, Sutiman, \& Akbar, 2016; Husamah, Fatmawati, \& Setyawan, 2017; Husamah, Pantiwati, \& Hudha, 2017).

Adapun bentuk pendampingan yang dilakukan adalah memberikan pengenalan dan implementasi model pembelajaran OIDDE untuk meningkatkan pembelajaran berorientasi etika pada semua guru MA Muhammadiyah I Plus Malang. Sehubungan dengan itu, artikel ini bertujuan mendeskripsikan implementasi kegiatan pendampingan implementasi model pembelajaran OIDDE untuk meningkatkan keterampilan pembelajaran berorientasi etika di MA Muhammadiyah 1 Plus Malang.

\section{Metode}

Subjek dalam pengabdian ini adalah guru (ustadz/ustadzah) MA Muhammadiyah 1 Plus Malang, yang berjumlah 21 orang. Kegiatan dilaksanakan selama 3 bulan. Alat yang digunakan dalam pengabdian adalah laptop, LCD, Screen, ATK, kamera, dan sound system. Bahan yang digunakan berupa print out materi/makalah, file pendukung presentasi, dan video model pembelajaran OIDDE. Metode dan langkah kegiatan pengabdian yang disepakati seperti pada Tabel 1.

Tabel 1. Prosedur kerja dan metode pelaksanaan pengabdian

\begin{tabular}{|c|c|c|}
\hline No & Langkah Kegiatan Pengabdian & Metode \\
\hline 1 & persepsi dengan & Diskusi \\
\hline & Muhammadiyah I Plus Malang & \\
\hline 2 & Workshop Pembelajaran OIDDE: & \\
\hline $\mathrm{a}$ & Sesi 1: Penyampaian materi pengantar & Ceramah interaktif \\
\hline b & $\begin{array}{l}\text { Sesi 2: Latar belakang pelaksanaan kegiatan dan best } \\
\text { practices implementasi pembelajaran OIDDE selama ini }\end{array}$ & Ceramah interaktif \\
\hline c & Sesi 3: Diskusi sintaks pembelajaran OIDDE & Diskusi \\
\hline $\mathrm{d}$ & $\begin{array}{l}\text { Sesi 4: Pendampingan penyusunan perangkat } \\
\text { pembelajaran OIDDE }\end{array}$ & Diskusi dan praktik \\
\hline $\mathrm{e}$ & $\begin{array}{l}\text { Sesi 5: Pendampingan implementasi pembelajaran } \\
\text { OIDDE }\end{array}$ & Diskusi dan pemodelan \\
\hline
\end{tabular}

Lembaga pendidikan yang menjadi mitra dalam kegiatan pengabdian ini adalah MA Muhammadiyah 1 Plus Malang, Bentuk partisipasi mitra dalam pelaksanaan program pengabdian kelompok ini, yaitu 1) menyediakan sumber daya manusia (para guru dari berbagai mata pelajaran untuk menjadi peserta pendampingan implementasi model pembelajaran OIDDE);2) menyediakan tempat dan ruang yang representatif untuk kelancaran pelaksanaan kegiatan pengabdian; dan 3) konsistensi serta antusiasme mengikuti kegiatan hingga selesai. Teknik pengumpulan data dilakukan dengan observasi atau kunjung langsung ke lokasi pengabdian, melakukan ceramah dan diskusi (sosialisasi), serta pendokumentasian kegiatan (catatan kegiatan dan analisis perangkat). Data-data yang berhasil dikumpulkan kemudian dianalisis secara deskriptif kualitatif yang didukung dengan data kuantitatif. Evaluasi kegiatan pengabdian dilakukan dari aspek proses. Keberhasilan proses dilihat dengan menghitung kehadiran guru dalam setiap sesi, dimana dianggap berhasil bila minimal $80 \%$ guru yang hadir dengan antusias (serius mengikuti pelatihan), minimal $80 \%$ aktif bertanya, dan ada perwakilan yang tunjuk oleh pihak madrasah untuk menjadi guru model (membuat perangkat dan modelling implementasi pembelajaran OIDDE).

\section{Hasil dan pembahasan}

Kegiatan pengabdain telah dilaksanakan selama \pm 3 bulan di MA Muhammadiyah I Plus Malang. Adapun uraian kegiatan beserta hasil yang dicapai adalah sebagai berikut. a. Penyamaan Persepsi dengan Pihak Sekolah

Kegiatan tersebut dilaksanakan pada bulan Mei 2019. Tim kembali menegaskan maksud dan tujuan kegiatan pengabdian. Tim juga mereview ulang berbagai hal yang telah disepakati pada saat obervasi 
awal, Tim dengan jelas dan gamblang menyampaikan menguraikan rencana tahapan kegiatan pengabdian yang akan dilaksanakan, termasuk peran dan kontribusi masing-masing pihak. Hasil dari kegiatan ini, yaitu bahwa Ibu Kepala Madrasah, Bapak Wakil Kepala Madrasah Bidang Humas, dan Perwakilan Guru menyampaikan bahwa mereka berkomitmen untuk bersama-sama menyukseskan kegiatan mengingat penting dan kemanfaatan bagi madrasah. Tema pengabdian sejalan dengan upaya sekolah untuk meningkatkan kualitas proses belajar dan mengajar (PBM) dan meningkatkan kualitas lulusan (alumni yang beretika baik). Pihak madrasah berjanji untuk segera menentukan jadwal yang tepat, serta mensosialisasikan dan menugaskan para guru untuk mengikuti kegiatan sesuai dengan tahapan yang telah ditetapkan. Madrasah juga menyiapkan ruang dan peralatan yang dibutuhkan. Pihak madrasah juga akan mengkomunikasikan kegiatan ini kepada para wali murid dan Majelis Pendidikan Dasar dan Menengah Pimpinan Daerah Muhammadiyah Kota Malang.

\section{b. Workshop Pembelajaran OIDDE}

Kegiatan dilaksanakan bulan Juli 2019 di Aula MA Muhammadiyah 1 Plus Malang mulai pukul 07.00 sampai pukul $15.00 \mathrm{WIB}$, diikuti sebanyak 27 orang peserta sebagaimana disajikan pada Tabel 2.

Tabel 2. Peserta pengabdian

\begin{tabular}{clcc}
\hline No & \multicolumn{1}{c}{ Peserta } & Jumlah (orang) & Keterangan \\
\hline & Kepala madrasah, wakil kepala & 21 & 21 orang guru aktif mengikuti kegiatan \\
1 & madrasah, dan guru & & secara penuh (100\%) \\
& (ustadz/ustadzah) & 2 & Aktif \\
2 & Tim Pengabdi & 4 & Aktif \\
3 & Tenaga pembantu dokumentasi & & \\
\hline
\end{tabular}

Pelaksanaan kegiatan ini dimulai dengan Sesi 1 berupa penyampaian materi pengantar. Tahap ini berupa sambutan/pengantar dari perwakilan madrasah. Pihak MA Muhammadiyah I Plus Malang sangat mengapresiasi pelaksanaan kegiatan ini, terutama karena tim pelaksana pengabdian telah memilih Lembaga mereka sebagai mitra. Kegiatan ini mendukung upaya madrasah untuk meningkatkan kualitas pelayanan kepada siswa/santri, khususnya dalam hal kualitas kegiatan belajar dan mengajar. Upayaupaya meningkatkan kompetensi para guru terkait model pembelajaran terkini, kontekstual, dan mendorong active learning. Harapanya, melalui kegiatan ini, para guru di MA Muhammadiyah I Plus Malang akan semakin profesional.

Sesi 2 adalah presentasi mengenai latar belakang pelaksanaan kegiatan dan best practices implementasi pembelajaran OIDDE selama ini. Tim menyampaikan berbagai kondisi yang menjadi latar belakang mengapa kegiatan pengabdian ini dilakukan, khususnya terkait dengan problema etik di masyarakat secara umum dan khususnya di sekolah serta siswa, tuntutan untuk berkolaborasi dengan sekolah/madrasah sebagai tanggung jawab tridharma perguruan tinggi, dan tren hasil penelitian dan publikasi yang telah dilaksanakan tim selama sepuluh tahun terakhir. Hasil-hasil penelitian dan publikasi berbasis Model Pembelajaran OIDDE juga dipaparkan sebagai bukti ilmiah penerapan model tersebut. Tim menegaskan bahwa Model Pembelajaran OIDDE telah diterapkan di puluhan sekolah di Malang Raya, baik level SMP, SMA, ataupun juga SMK. Model tersebut juga banyak dipakai dalam pembelajaran oleh para dosen, khususnya di lingkungan Program Studi Pendidikan Biologi, Fakultas Keguruan dan Ilmu Pendidikan Universitas Muhammadiyah Malang. Hasil dari kegiatan ini berupa adanya penyamaan pemahaman terkait tema pengabdian, alasan dan landasan empiris serta filosofis mengapa perlu kegiatan pengabdian, dan alasan mengapa tema pengabdian pendampingan implementasi model pembelajaran OIDDE untuk meningkatkan keterampilan pembelajaran berorientasi etika di MA Muhammadiyah 1 Plus Malang sangat perlu untuk dilaksanakan. Semua guru menyampaikan kesamaan pikiran mereka terkait permasalahan tersebut, dan memang menganggap bahwa problema etika mendesak untuk direspon. Mereka sebagai guru memiliki peran strategis untuk terlibat menyelesaikan atau mengatasi problema etika, terlepas apapun mata pelajaran yang diampu.

Sesi 3 berupa presentasi sintaks pembelajaran OIDDE dan contoh implementasinya (modelling). Tim mempresentasikan latar belakang pengembangan model OIDDE dan menjelaskan tahapan/sintaks pembelajaran secara terperinci. Pada tahap ini disampaikan pula bagaimana implementasi model ini secara nyata, dimana ketua pelaksana berperan sebagai guru dan para peserta berperan sebagai siswa/santri. Setelah pemodelan, dilakukan sesi pemantapan dan tanya jawab. Para guru bertanya berbagai hal, khususnya strategi mengatur waktu, cara memastikan penerapan sintaks dengan tepat, penilaian siswa, dan mengukur perkembangan dan perubahan aspek etika. Berdasarkan tahapan tersebut, para guru tampak sangat antusias mengikuti modelling yang dilakukan dan aktif bertanya/berdiskusi. 
Menurut mereka model ini sangat mengasyikkan, membuat siswa dan guru lebih aktif, dan mudah dilaksanakan sesuai urutan karena sesuai dengan namanya (akronim/singkatan).

Sesi 4 yaitu pendampingan penyusunan perangkat pembelajaran OIDDE. Pada sesi ini ditetapkan seorang guru yang menjadi "Master Teacher" atau "Guru Model". Berdasarkan kesepatan guru yang terpilih adalah guru mata pelajaran biologi. Sesi ini dilaksanakan dengan tatap muka langsung bersama guru dan menggunakan email serta WhatsApp. Guru mengirimkan perangkat pembelajaran yang telah dikembangkan sesuai dengan sintaks OIDDE dan selanjutnya tim memberikan masukan dan saran revisi.

Sesi kelima berupa pendampingan terhadap guru dalam melaksanakan praktik pembelajaran (open class) berbasis model pembelajaran OIDDE. Guru telah mengimplementasikan model pembelajaran OIDDE di kelas. Guru menerapkan model tersebut untuk meningkatkan kemampuan pengambilan keputusan etis siswa pada mata pelajaran biologi kelas X. Adapun komentar guru terhadap model pembelajaran OIDDE berdasarkan refleksi implementasi yang telah dilakukan, seperti pada Tabel 3.

Berdasarkan Tabel 3, dapat dikatakan bahwa "Master Teacher" atau "Guru Model" mennegaskan model model Pembelajaran OIDDE merupakan hal yang baik/positif dalam upaya meningkatkan kualitas pembelajaran yang dilakukan. Dalam praktik selanjutnya, perlu diperhatikan hal-hal berikut, 1) yaitu waktu pembelajaran perlu diperhatikan secara detail, khususnya tahapan diskusi, 2) mencari masalah etik dalam bidang biologi merupakan tantangan tersendiri bagi guru, dan 3) model ini akan lebih maksimal bila dilakukan dalam bentuk team teaching dan dengan pendekatan lesson study.

Tabel 3. Komentar Guru terhadap Model Pembelajaran OIDDE

\begin{tabular}{cl}
\hline No & \multicolumn{1}{c}{ Respon/Catatan Guru } \\
\hline 1 & Memberikan pengetahuan dan keterampilan baru berupa alternatif model pembelajaran \\
& berorientasi etika \\
2 & Pembelajaran menjadi lebih aktif, menantang, dan produktif \\
3 & Sangat potensial untuk ber-PTK \\
4 & Waktu pembelajaran perlu diperhatikan secara detail, khususnya tahapan diskusi \\
5 & Mencari masalah etik dalam bidang biologi merupakan tantangan tersendiri bagi guru \\
6 & Model ini akan lebih maksimal bila dilakukan dalam bentuk team teaching dan dengan \\
& pendekatan lesson study \\
\hline
\end{tabular}

Pembelajaran berorientasi etika merupakan hal yang sangat penting, khususnya di level sekolah menengah atas (SMA). Bagaimanapun, siswa mengembangkan banyak keterampilan sebagai hasil dari belajar etika di sekolah menengah. Pola ini memberikan siswa kesempatan untuk mengeksplorasi dan mengevaluasi berbagai pendapat dan membandingkannya dengan pendapat mereka sendiri. Ini mendoron berkembangnya pemikiran kritis, yang bermanfaat untuk praktik sebelum membuat keputusan. Berpikir kritis tentang situasi juga dapat mencegah siswa dari membabi buta mengikuti orang lain tanpa mempertimbangkan pilihan alternatif. Pembelajaran berorientasi etika memberikan cara bagi siswa untuk terlibat dalam diskusi intelektual, meningkatkan penalaran moral, dan mengeksplorasi jawaban atas pertanyaan yang bermakna tentang kehidupan.

Sejalan dengan permasalahan tersebut, hal yang dapat dilakukan guru terkait etika siswa selain memberikan teladan, membentuk lingkungan kondusif, menjaga kedekatan dengan siswa, dan mengkoreksi kekeliruan siswa adalah dengan melakukan pembiasaan dengan mengintegrasikan dalam pembelajaran secara tepat (Wuryandani, Fathurrohman, \& Ambarwati, 2016). Guru akan berkontribusi pada etika siswa jika mereka menjalani tugas berdasar kemampuan mereka sendiri untuk melakukan, dan kebebasan mereka untuk merenungkan pekerjaan yang dilandasi rasa hormat terhadap diri mereka sendiri dan mempraktekkan apa yang mereka ajarkan (Opazo, Aramburuzabala, \& García-Peinado, 2014). Pendampingan guru mengembangkan perilaku etis siswa berbasis pembelajaran OIDDE sangat penting dilakukan, mengingat guru adalah aktor utama dalam menanamkan karakter dan nilai-nilai etis (Husamah, Hudha, \& Pantiwati, 2018).

Kegiatan pengabdian ini telah memberikan salah satu alternatif pembelajaran berorientasi etika yang dapat diimplementasikan oleh guru, yaitu Model Pembelajaran OIDDE. Hasil positif dari pengabdian ini sejalan dengan pengabdian yang telah dilaksanakan oleh Husamah et al., (2018) sebelumnya, dimana guru secara umum mengatakan hal yang positif terlait Model Pembelajaran OIDDE. Model ini mampu memberikan pengetahuan baru tentang alternatif model pembelajaran yang berhubungan dengan karakter, moral, dan etika.

Apabila model Model Pembelajaran OIDDE ini konsisten dilakukan, maka aspek pertimbangan etis siswa sangat dimungkinkan akan semakin baik. Hal ini sejalan dengan Fariati et al., (2017) bahwa model 
Pembelajaran OIDDE dapat meningkatkan pemahaman siswa SMK sehingga membantu mereka dalam memilih jawaban yang paling tepat. Hal ini dimungkinkan karena adanya penguatan terhadap pertimbangan etis siswa. Kemampuan para siswa untuk mengindentifikasi berbagai faktor penyebab dan pendorong perilaku seks pranikah, dampak dan risiko perilaku seks pranikah, faktor dan dampak aborsi, dan berbagai hal lain yang terkait dengan tema itu mengindikasikan bahwa pengetahuan siswa cukup baik atau tinggi, dan berarti sangat positif bagi siswa.

\section{Simpulan dan saran}

Kegiatan pengabdian telah dilaksanakan sesuai dengan rencana, dengan kegiatan berupa penyamaan persepsi dengan pihak MA Muhammadiyah I Plus Malang dan Workshop Pembelajaran OIDDE. Workshop terdiri atas 5 sesi, yaitu a) Penyampaian materi pengantar; b) Latar belakang pelaksanaan kegiatan dan best practices implementasi pembelajaran OIDDE selama ini; c) Diskusi sintaks pembelajaran OIDDE; d) Pendampingan penyusunan perangkat pembelajaran OIDDE; dan Pendampingan implementasi pembelajaran OIDDE. Saran untuk kegiatan selanjutnya adalah perlunya perluasan cakupan atau mitra sasaran, perlunya pendampingan guru dalam pelaksanaan PTK berbasis pembelajaran OIDDE, dan pendampingan pembentukan team teaching serta implementasi lesson study sehingga diharapkan terus meningkatkan profesionalisme para guru.

\section{Daftar Rujukan}

Akbar, S. (2011). Revitalisasi pendidikan dasar di sekolah dasar. In Makalah Sidang Terbuka Senat Universitas Malang pada Pidato Pengukuhan Guru Besar Dalam Bidang Ilmu Pendidikan/Pendidikan Dasar. Malang: Universitas Negeri Malang.

Banks, S. (2016). Everyday ethics in professional life: Social work as ethics work. Ethics and Social Welfare, 10(1), 35-52. https://doi.org/10.1080/17496535.2015.1126623

Chowdhury, M. (2016). Emphasizing morals, values, ethics, and character education in science education and science teaching. Malaysian Online Journal of Educational Sciences, 4(2), 1-16. Retrieved from https://files.eric.ed.gov/fulltext/EJ1095995.pdf

Elliott, D. (2009). Ethical challenges: Building an ethics toolkit. Bloomington, Indiana: AuthorHouse.

Fariati, E., Hudha, A. M., \& Husamah, H. (2017). Pengetahuan dan keputusan etis siswa SMK Negeri 6 Malang terhadap permasalahan perilaku seks pra nikah melalui pembelajaran model OIDDE. In H. Husamah \& F. H. Permana (Eds.), Prosiding Seminar Nasional III Tahun 2017 kerjasama Prodi Pendidikan Biologi FKIP dengan Pusat Studi Lingkungan dan Kependudukan (PSLK) Universitas Muhammadiyah Malang (pp. 158-166). Malang, Indonesia: UMM Press \& PSLK UMM.

Gilman, S. C. (2005). Ethics codes and codes of conduct as tools for promoting an ethical and professional public service: Comparative successes and lessons (Winter 200). Washington, DC: PREM, the World Bank.

Gluchmanova, M. (2015). The importance of ethics in the teaching profession. In Procedia - Social and Behavioral Sciences (Vol. 176, pp. 509-513). Elsevier B.V. https://doi.org/10.1016/j.sbspro.2015.01.504

Gülcan, N. Y. (2015). Discussing the importance of teaching ethics in education. In Procedia - Social and Behavioral Sciences (Vol. 174, pp. 2622-2625). Elsevier B.V. https://doi.org/10.1016/j.sbspro.2015.01.942

Hudha, A. M., Amin, M., Sumitro, S. B., \& Akbar, S. (2018). The effectiveness of OIDDE learning model in the improvement of bioethics knowledge, ethical decision, and ethical attitude of biology pre- service teachers. Journal of Baltic Science Education, 17(6), 960-971.

Hudha, A. M., Amin, M., Sutiman, B. S., \& Akbar, S. (2016). Study of instructional models and syntax as an effort for developing "OIDDE" instructional model. JPBI (Jurnal Pendidikan Biologi Indonesia), 2(2), 109-124. https://doi.org/10.22219/jpbi.v2i2.3448 
Husamah, H., Fatmawati, D., \& Setyawan, D. (2017). Model pembelajaran OIDDE pada matakuliah pengetahuan lingkungan untuk meningkatkan keterampilan berpikir kritis mahasiswa calon guru biologi. BIOEDUKATIKA, 5(2), 73-85. https://doi.org/10.26555/bioedukatika.v5i2.7321

Husamah, H., Hudha, A. M., \& Pantiwati, Y. (2018). Pendampingan guru SMPN 8 Kota Malang dalam mengembangkan perilaku etis siswa berbasis model pembelajaran OIDDE. International Journal of Community Service Learning, 2(2), 41-50. https://doi.org/10.23887/ijcsl.v2i2.14185

Husamah, H., Pantiwati, Y., \& Hudha, A. M. (2017). OIDDE learning model through integrated field studies abroad to develop ethical decision skills of candidate biology teachers: Indonesian perspective. Educational Process: International Journal, 6(4), 7-19. https://doi.org/10.22521/edupij.2017.64.1

Iorga, M., Ciuhodaru, T., \& Romedea, S.-N. (2013). Ethic and unethic. Students and the unethical behavior during academic years. In Procedia - Social and Behavioral Sciences (Vol. 93, pp. 54-58). Elsevier B.V. https://doi.org/10.1016/j.sbspro.2013.09.151

Latif, N. (2016). Etika religius sebagai dasar pengembangan sains (Konstruksi pemikiran etika Ismā'il Rāji al-Fārūqī). In Proceeding of International Conference On Islamic Epistemology (pp. 194-200). Surakarta: Universitas Muhammadiyah Surakarta. Retrieved from https://publikasiilmiah.ums.ac.id/bitstream/handle/11617/8069/22.pdf?sequence=1\&isAllowed $=\mathrm{y}$

Lesna-Wierszolowicz, E. (2012). The importance of ethics in business. Folia Pomeranae Universitatis Technologiae Stetinensis, 298(69), 39-48. Retrieved from http://agro.icm.edu.pl/agro/element/bwmeta1.element.agro-77c1382c-2474-4016-97659437a33f69a8/c/Lesna_Wierszolowicz.pdf

Maftuh, B. (2016). Improving the quality of education in the future. In 7 th International Conference. Surabaya: University PGRI Adibuana Surabaya.

Opazo, H., Aramburuzabala, P., \& García-Peinado, R. (2014). Service-learning methodology as a tool of ethical development: Reflections from the university experience. AISHE-J - The All Ireland Journal of Teaching and Learning in Higher Education, 6(1), 15310-15326. Retrieved from http://ojs.aishe.org/index.php/aishe-j/article/viewFile/153/248

Setyaningrum, Y., \& Husamah, H. (2011). Optimalisasi penerapan pendidikan karakter di sekolah menengah berbasis keterampilan proses: Sebuah perspektif guru IPA-biologi. Jurnal Penelitian Dan Pemikiran Pendidikan, 1(1), 69-81. Retrieved from http://ejournal.umm.ac.id/index.php/jp3/article/view/616

Weisman, S. R. (Ed.). (2013). Ethics and globalization: The tradeoffs underlying our policy choices. Washington, DC: Peterson Institute for International Economics. Retrieved from https://www.piie.com/sites/default/files/publications/papers/ethics_globalization_conference_e book.pdf

Wuryandani, W., Fathurrohman, F., \& Ambarwati, U. (2016). Implementasi pendidikan karakter kemandirian di Muhammadiyah Boarding School. Jurnal Cakrawala Pendidikan, 15(2), 208-216. https://doi.org/10.21831/cp.v15i2.9882 